\title{
KESADARAN PENERAPAN PRINSIP BUSINESS ENTITY: STUDI PADA STARTUP DI YOGYAKARTA
}

\author{
Siti Afidatul Khotijah, Retnosari, Risma Wira Bharata \\ Universitas Tidar, Indonesia \\ khotijah_afi@untidar.ac.id
}

\begin{abstract}
Startup is a business that has emerged in the modern era and is used through online media. Most of the startups are young people. This research aims to to analyze business awareness starting from being launched by the younger generation, in applying the concept of business entities. This research uses a qualitative case study design to find out about initiating awareness in implementing business entities. Data collection is done by gathering interviews with startups. The results of this study indicate that startup companies already have an awareness of the concept of business entities that cannot be applied to KEVAmedia because human resources are still limited, so the division of tasks cannot be carried out. Sustainability investors are also one of the reasons startups prepare financial reports that are in accordance with accounting principles and apply concepts in accounting.
\end{abstract}

Keywords: Startup; Entity Business; Bookkeeping.

\section{Abstrak}

Startup menjadi bisnis yang muncul di era modern sekarang ini dan cenderung dimanfaatkan dengan media online. Sebagian besar pelaku usaha startup adalah dari kalangan muda. Penelitian ini bertujuan untuk menganalisis kesadaran pelaku usaha terutama start up yang biasanya dijalankan oleh generasi muda, dalam penerapan konsep business entity. Pendekatan kualitatif digunakan di dalam penelitain ini, dengan desain studi kasus untuk mengetahui kesadaran start-up dalam menerapkan business entity. Pengumpulan data dilakukan dengan metode wawancara mendalam pada pelaku startup. Hasil dari penelitian ini menunjukkan bahwa pelaku startup sudah memiliki kesadaran pentingnya menerapkan konsep business entity namun belum bisa diterapkan pada KEVAmedia karena kendala sumber daya manusia yang masih terbatas, sehingga pembagian tugas belum bisa dilaksanakan. Keberadaan investor juga menjadi salah satu alasan startup untuk menyusun laporan keuangan sesuai kaidah akuntansi dan menerapkan konsepkonsep dalam akuntansi.

Kata kunci : Startup; Bisnis Entity; Pembukuan.

\section{Pendahuluan}

Perusahaan startup dikenal lingkup bisnis pada perusahaan sebagai perusahaan berbasis digital. Pada umumnya, e-commerce atau perdagangan online menjadi ruang startup (Yanuarti \& Dewi, 2018). Berdasarkan informasi dari website 
Kominfo menyebutkan data terbaru dari situs registrasi perusahaan rintisan bahwa Indonesia menempati posisi kelima di dunia dengan memiliki 2.079 perusahaan rintisan. Sedangkan berdasarkan catatan dari Masyarakat Industri Keatif Teknologi Informasi dan Komunikasi Indonesia (MIKTI), hingga tahun 2018 mencatat terdapat 992 perusahaan rintisan. Informasi tersebut diperoleh dengan mengakses situs perusahaan terkait dan verifikasi langsung ke lapangan. Dalam catatan MIKTI menemukan $60,20 \%$ para pendiri startup itu adalah generasi muda yang berpendidikan Strata 1 (Wijanarko, 2019).

Tujuan pada perusahaan startup yaitu mendapatkan keuntungan atau profit, sama dengan tujuan perusahaan-perusahaan terbuka lainnya. Perusahaan startup relatif lebih sulit dalam menyediakan data historis keuangan karena usia perusahaan startup yang cenderung masih dalam tahap awal (kurang dari atau sama dengan satu tahun. Disisi lain, riwayat laporan keuangan yang disediakan suatu perusahaan menjadi salah satu alasan yang mempengaruhi minat para investor untuk investasi pada perusahaan. Para calon investor akan melihat apakah riwayat keuangan mengalami peningkatan atau penurunan dari tahun ke tahun. Kejadian seperti ini menjadi hambatan sulit masuknya dana segar baik dari investor ataupun dana dari pasar modal bagi perusahaan startup. Hal ini bukan merupakan hambatan bagi perusahaan terbuka lainnya, karena perusahaan terbuka lain yang sudah lama berdiri memiliki rekam jejak (track record) mengenai kondisi perusahaan mereka terutama dalam hal keuangan. Rekam jejak ini akan membuktikan keuntungan yag dihasilkan untuk kelangsungan perusahaan. Dengan begitu, para investor akan menjadi percaya dan akhirnya bersedia untuk melakukan investasi pada perusahaan terbuka tersebut (Damodaran, 2009).

Perusahaan startup cenderung bergantung pada modal pribadi yang disetorkan oleh pemilik perusahaan. Hal itu terjadi karena perusahaan startup mengalami kesulitan dalam pengumpulan dana atau pengumpulan modal dari para calon investor ataupun pasar modal. Pada awal operasinya, perusahaan startup lebih banyak menggunakan dana ekuitas 
(setoran modal pemilik). Perusahaan startup rentan mengalami kegagalan karena modal yang digunakan hanya tergantung pada satu pihak saja. Biasanya hal ini terjadi pada masa awal berdirinya perusahaan. Perusahaan startup harus bergerak dengan cepat untuk memperoleh arus kas (cash flow). Hal tersebut bida dilakukan oleh perusahaan dengan melihat peluang yang masyarakat butuhkan secara jeli dan sebisa mungkin menyediakan produk maupun jasa yang dibutuhkan masyarakat sebelum yang lain mengikuti (Patel, 2011).

Penggunaan modal dari pribadi sekaligus pemilik yang mengoperasikan perusahaan cenderung mengabaikan konsep business entity. Busines entity secara umum dapat diartikan dengan pemisahan harta antara pemilik modal dengan harta yang digunakan untuk bisnis. Sebagian pelaku usaha masih tidak memperdulukan konsep ini. Para pemilik sering menggunakan dana perusahaan untuk keperluan pribadi maupun sebaliknya, tanpa catatan yang resmi dan jelas. Pemilik sering berpikir bahwa hal ini tidak masalah dan menganggap ini merupakan hal yang kecil, padahal konsep bisnis entity ini sangat penting untuk berlangsungnya suatu usaha.

Penelitian terdahulu yang dilakukan berkaitan dengan faktor yang mempengaruhi keberhasilan suatu usaha start up dilakukan oleh Jaya dkk (2017). Penelitian tersebut menjelaskan bahwa keberhasilan suatu bisnis dipengaruhi oleh beberapa faktor diantaranya sumber daya manusia atau tim yang baik, grup/tim yang tepat, ide yang kreatif serta pendanaan yang cukup. Penelitian lain dilakukan oleh Gloor dkk. (2011) yang menemukan bahwa kedekatan dengan orang-orang kunci dalam media sosial mempengaruhi kesuksesan suatu bisnis baru. Penelitian serupa dilakukan oleh Perdani dkk. (2018) menjelaskan bahwa pengalaman kerja pengusaha menjadai faktor yang mempengaruhi pertumbuhan bisnis startup.

Penelitian yang menganalisis konsep business entity pada starup belum dilakukan sebelumnya. Berdasarkan latar belakang diatas, penulis akan menganalisis kesadaran pelaku usaha terutama start up yang biasanya dijalankan oleh generasi muda, dalam penerapan konsep 
business entity. Analisis ini dilakukan untuk menggali lebih dalam apakah business entity menjadi salah satu faktor keberhasilan dalam usaha.

\section{Landasan Teori dan Pengembangan Hipotesis Teori Kesadaran (Consciousness)}

Kesadaran dapat diartikan sebagai kondisi ketika seorang individu memiliki kendali penuh terhadap stimulus secara internal maupun stimulus secara eksternal. Sigmund Freud (1923) dalam (Ginintasasi，2013) mengemukakan teori kesadaran yang secara umum menyatakan bahwa kesadaran merupakan suatu bagian terkecil atau bagian tipis dari keseluruhan pikiran manusia. Malikah (2013) menyatakan bahwa id, ego dan superego merupakan struktur jiwa yang menjadi penentuan aktivitas manusia. Carl Gustav Jung (1989) yang merupakan tokoh selain Sigmund Freud, juga berpendapat mengenai teori kesadaran yang menyatakan bahwa 3 sistem yang saling berhubungan akan membentuk kesadaran. Sistem tersebut terdiri dari ego, personal unconcious dan collective unconcious (Ginintasasi, Kesadaran, t.thn.).
Seseorang memiliki 3 sistem yang harus seimbang antara id, ego, dan superego, maupun keseimbangan antara ego, personal unconscius, dan collective. Keseimbangan tersebut menentukan aktivitas yang akan dilakukan oleh seseorang, termasuk dalam pengambilan suatu keputusan. Hal tersebut juga berlaku bagi pengusaha dalam melakukan pengambilan keputusan dalam permodalan usahanya. Pengusaha yang menyadari akan pentingnya business entity, akan berhati-hati dalam menggunakan uang pribadi dan uang perusahaan serta akan mencatat dengan detail setiap transaksi yang terjadi.

\section{Start Up}

Media online yang sering disebut $e$ commerce saat ini cenderung dimanfaatkan untuk menjalankan sautau bisnis di era modern. Pada era digital saat ini, startup merupakan kata yang sering digunakan. Sheung (2014) menjelaskan bahwa inovasi tren teknologi menjadi acuan dalam metode startup bisnis. Tren yang mengubah model bisnis tradisional atau mendorong berdirinya bisnis baru (startup) dipengaruhi oleh 
Siti Afidatul Khotijah, Retnosari, Risma Wira Bharata

percepatan pertumbuhan Teknologi digital, dan 7) Umumnya Informasi dan Komunikasi (ICT). beroperasi dan bergerak berbasis Pertumbuhan ini cenderung website dan online, serta 8) memanfaatkan peluang teknologi Pelakunya mayoritas pemuda. yang kemudian diterapkan untuk Prinsip Entitas Bisnis berbagai bidang kehidupan. Bisnis Baridwan, (1992:8) dalam dengan model Startup mampu (Oesman, 2010) menyebutkan bahwa menciptakan peluang baru bagi kesatuan usaha khusus merupakan masyarakat dan khususnya bagi para suatu konsep ketika perusahaan generasi muda yang mau beradaptasi dipandang sebagai suatu unit usaha dan bersedia mengubah model bisnis yang berdiri sendiri. Perusahaan juga dari pasar tradisional ke pasar virtual. harus terpisah dari pemiliknya atau Model bisnis lama yang masih dari kesatuan usaha yang lain. manual mulai berubah ke model Perusahaan dipisahkan secara bisnis yang dijalankan secara online pencatatan dari pemegang saham (startup). Model ini menggantikan (pemilik) maupun pemilik modal inventaris dengan informasi dan untuk tujuan akuntansi. Dengan produk barang fisik digantikan anggapan ini, maka pencatatan dengan produk digital (Nugraha \& transaksi perusahaan harus dipisahkan Wahyuhastuti, 2017).

Secara umum perusahan startup memiliki beberapa karakter (Ryandono, 2018), yaitu 1) dari transaksi yang dilakukan pemilik. Hal tersebut berimbas pada semua pencatatan dan laporan keuangan dibuat untuk kepentingan perusahaan Perusahaan berumur kurang dari 3 tahun; 2) Karyawan yang dimiliki kurang dari 20 orang; 3) Omset penjualan pertahun kurang dari $\$ 100.000,00$; 4) Perusahaan dalam tahap perkembangan; 5) Mayoritas bergerak dalam bidang teknologi; 6) Produknya pada umumnya berbasis aplikasi dalam model saja, bukan untuk kegiatan yang dilakukan pemilik secara pribadi. Konsep entitas ini penting untuk bisa diterapkan dalam suatu bisnis karena menentukan bidang kepentingan. Dengan demikian, konsep ini juga akan mempersempit objek dan kegiatan yang dapat dimasukkan kedalam laporan keuangan maupun 
yang tidak dapat dimasukkan dalam transaksi laporan keuangan perusahaan. Sifat suatu entitas akan membantu dalam menentukan cara terbaik menyajikan suatu informasi mengenai kesatuan dan mempersempit pilihan transaksi dan informasi apa yang dimasukkan dalam laporan keuangan. Dengan demikian, aspek relevan dalam suatau informasi dapat diungkapkan dan aspek tidak relevan yang mengaburkan informasi dasar dapat ditiadakan (Sinaga, 1994).

Webster Dictionary (1991: hal. 453) menjelaskan makna entitas, bahwa entitas dimaksud sebagai "thing that has definite, individual existence outside or within the mind; anything real in itself". Jika dilihat dari sisi ekonomi maupun dari sisi pendekatan hukum, dari definisi tersebut dapat diartikan bahwa entitas merupakan suatu keberadaan individu yang dapat berdiri sendiri. Dari makna ekonomi, keberadaan suatu entitas terpisah dari orang atau badan lain. Selain itu suatu entitas juga harus memiliki otoritas sendiri dalam mengatur ekonomi maupun keuangannya. Sedangkan dari pendekatan hukum, dapat dijelaskan bahwa keberadaan individu merupakan suatu badan hukum tersendiri yang didalamnya melekat hak dan kewajiban yang berkaitan dengan peraturan yang berlaku di lingkungan entitas tersebut berada. Menurut (Kam, 1990: hal. 303-320) dalam (Isgiyarta, 2009) menjelaskan bentuk dari entitas menurut akuntansi konvensional, yaitu proprietary theory, entity theory, fund theory, commander theory, investor theory, dan enterprises theory.

\section{Metode Penelitian}

Pendekatan kualitatif digunakan pada penelitian ini. Desain studi kasus digunakan untuk mengetahui kesadaran start-up dalam menerapkan business entity, secara khusus startup yang ada di Kota Yogyakarta. Pemeriksaan terhadap kejadian atau pengalaman dari perspektif individu dilakukan dalam pendekatan kualitatif. Pendekatan ini juga melibatkan langsung seseorang yang mengalami fenomena. Informasi yang lebih mendalam menjadi salah satu keuntungan dari penelitian kualitatif. Dengan begitu akan diperoleh informasi secara komprehensif berkaitan dengan topik yang sedang diteliti. Pengumpulan data dilakukan 
Siti Afidatul Khotijah, Retnosari, Risma Wira Bharata

dengan mewancarai CEO/ orang yang

memiliki peran inti dalam startup atau

disebut wawancara mendalam

(indepth interview). Wawancara face-

to-face juga dilakukan untuk

mendapatkan pemahaman yang lebih

mendalam dari responden. Selain itu,

observasi juga dilakukan dengan

melihat kondisi start-up dan melihat

sekilas laporan keuangan yang telah

disusun. Studi literatur menjadi

tahapan awal dalam penelitian ini.

Hal ini dilakukan dengan mencari data-data yang berkaitan dengan topik penelitian serta literatur yang menjadi landasan teori dari penelitian ini. Tahapan selanjutnya yaitu mengumpulkan data dilapangan dengan cara observasi dan wawancara mendalam secara langsung terhadap salah satu startup yang ada di Yogyakarta. Peneliti memilih Kota Yogyakarta karena di kota tersebut, banyak mahasiswa yang memiliki startup. Data yang diperoleh kemudian diolah dan dianalisis untuk dicocokan dengan teori-teori terdahulu untuk ditarik suatu kesimpulan mengenai kesadaran startup dalam menerapkan business entity untuk kemudian dilakukan penelitian lebih lanjut mengenai faktor penerapan business entity.

\section{Hasil dan Pembahasan \\ Profil KEVAmedia}

KEVAmedia adalah platform usaha di bidang industri dan jasa kreatif sebagai pusat produsen souvenir goodie bag (seminar kit), merchandise, tas promosi, produk konveksi (seperti kaos, polo, jaket, PDL, almamater, pakaian olahraga dan baju seragam), percetakan dan jasa desain di Daerah Istimewa Yogyakarta dengan pelayanan di seluruh Indonesia dalam menyediakan kebutuhan events dan perusahaan sebagai produk marketing kit dan souvenir promosi yang disajikan dalam bentuk produk sehingga bermanfaat dan produk promosi yang tahan lama. Startup desain menunjukkan bahwa komersialisasi ide adalah faktor paling penting untuk kesuksesan startup, sedangkan startup teknologi mengatakan investasi berkelanjutan adalah aspek yang paling penting, diikuti oleh komersialisasi ide. Startup desain harus mencoba membuat desain baru secara konstan, menghasilkan produk baru dengan menerapkan yang baru ide, dan 
waspadai persyaratan pasar dan perubahan lingkungan. Selain itu, startup desain harus menyiapkan model bisnis dan konten terkait pendapatan yang dibutuhkan oleh investor secara menyeluruh sehingga investasi dan dukungan yang stabil dapat diberikan kepada mereka pada waktu yang tepat (Kim, Kim, \& Jeon, 2018). KEVAmedia yang merupakan satu dari startup yang bergerak dalam bidang desain harus bisa terus mengembangkan idenya.

\section{Keunggulan}

memilih

produsen KEVAmedia sebagai penyedia souvenir merchandise dan goodie bag (seminar kit) untuk events dan perusahaan adalah (KEVA media, 2019): 1.) Kemudahan dalam mendapatkan pilihan paket goodie bag dan banyak pilihan bentuk merchandise yang diinginkin serta bisa mengajukan request bentuk produk; 2.) Mengutamakan kualitas bahan yang unggul dari produk lokal Indonesia dan Impor; 3.) Proses produksi yang super cepat dengan jam kerja produksi 24 jam dengan 3 kali shift untuk para pekerja sehingga pemesanan ratusan pieces produk konveksi dan produk yang sudah ready dapat dikerjakan dalam waktu
5-7 hari kerja; 4.) Layanan free custom design sesuai konsep dan konten dari pelanggan; 5.) Kemudahan pengiriman dengan layanan tanpa biaya untuk pengiriman ke-Seluruh daerah di Indonesia; 6.) Pemesanan souvenir merchandise minim budget dengan kemudahan penawaran based on budget. Sejak 2015 KEVAmedia sudah menjadi partner dan dipercaya oleh beberapa event, instansi maupun perusahaan di Indonesia dalam menyediakan souvenir merchandise dan goodie bag bagi mereka.

\section{Tata Kelola Keuangan}

Start-up hanyalah fase awal dari siklus hidup perusahaan diikuti oleh fase pertumbuhan atau scaling di mana potensi pertumbuhan start-up dapat berkembang menjadi perusahaan pertumbuhan tinggi yang membawa pendapatan, pekerjaan yang dibayar dengan baik dan memiliki kewajiban untuk membayar pajak (Zajko, 2017). KEVAmedia merupakan suatu usaha yang bermula dari kegiatan inkubasi bisnis mahasiswa, yang kemudian berlanjut menjadi sebuah bisnis yang hingga saat ini masih terus dijalankan. UKM yang inovatif ditumbuhkembangkan 
Siti Afidatul Khotijah, Retnosari, Risma Wira Bharata

oleh Inkubator Bisnis. Hal tersebut ditetapkan. Meskipun begitu, kedua dikarenakan melalui Inkubator Bisnis pemilik bisnis juga berkontribusi menjadikan embrio-embrio wirausaha dalam bisnis tersebut, sehingga setiap baru berbasis IPTEK yang dapat bulan juga akan menerima gaji secara ditingkatkan kapasitas dan kinerja usahanya (Mahani, 2015).

Sebagai bisnis yang bermula dari kecil, modal yang digunakan juga tidak besar. Bisnis ini juga belum mendapatkan investor dari pihak luar. Sumber dana hanya berasal dari pemilik yang berpartner dengan orang lain, sehingga bisa dibilang bisnis ini dimiliki oleh 2 orang. Tindakan kemitraan mengandung banyak ketentuan standar yang mengatur hubungan di antara mitra, antara mitra dan kemitraan, dan antara kemitraan dan pihak ketiga. Dalam rangka menghindari hal yang tidak diinginkan dalam operasi kemitraan, para kedua pihak harus menyetujui persetujuan kemitraan tertulis sebelum membentuk kemitraan (Matheson, 2002). Penerapan pencatatan pembagian kepemilikan dan tanggung jawab pada KEVAmedia sudah mengikuti pedoman tersebut, sehingga ketika ada keuntungan maupun kerugian, besarnya porsi penghasilan dan porsi tanggungan rugi juga sudah resmi. Meskipun begitu, menurut Matheson (2002) dalam penelitiannya menjelaskan bahwa sebagian besar pemilik bisnis akan memilih bentuk organisasi yang membatasi tanggung jawab pribadi, menjadikan kepemilikan tunggal sebagai pilihan yang kurang disukai. Ketika perusahaan hanya dimiliki oleh satu orang saja, maka resiko kerugian juga hanya akan ditanggung oleh satu orang saja, sedangkan jika dimiliki beberapa orang dengan bermitra, maka resiko kerugian juga bisa dibagi.

Seorang wirausahawan harus menemukan modal yang memadai untuk menjalankan bisnis, mengidentifikasi, dan mendapatkan dedikasi karyawan untuk bisnis, memberikan produk atau layanan yang menarik bagi konsumen, dan bersaing dengan pemain mapan di pasar (Franklin, 2016). Berkaitan dengan modal yang memadai, KEVAmedia masih sangat terbatas untuk urusan permodalan, sehingga dalam setiap proyek pesanan, 
customer harus membayarkan $50 \%$ dari harga pesanan. Keterbatasan modal tersebut menjadi slah satu kendala berkembangnya suatu bisnis. Salah satu jalan keluar untuk permodalan adalah melalui investor. Modal merupakan hal yang penting dalam bisnis, tetapi dalam praktiknya bukanlah aspek yang terpenting. Pendanaan untuk startup bisa berasal dari pemilik sendiri, angel investor, Institutionalized Investor dan bank (Rahardjo, t.th).

Bisnis yang memperoleh pendanaan dari investor harus memenuhi beberapa syarat untuk mendapatkan kepercayaan investor. Secara umum, investor akan membuat keputusan investasi berdasarkan pada nilai intrinsik perusahaan atau berdasarkan pada pertumbuhan profitabilitas perusahaan dari periode sebelumnya. Untuk mengukur referensi tersebut, investor memerlukan data historis laporan keuangan sebagai dasar untuk menghitung dan untuk perbandingan. Hambatan bagi perusahaan startup adalah kurangnya atau tidak tersedianya data keuangan historis karena starup pastinya belum memiliki pembukuan yang mengenai usaha yang sudah berjalan kurang dari satu tahun (Yanuarti \& Dewi, 2018). Tidak tersedianya data keuangan yang lengkap juga menjadi salah satu hambatan KEVAmedia untuk memperoleh pendanaan dari investor. Berdasarkan wawancara dan observasi peneliti, laporan keuangan pada KEVAmedia sudah dibuat, namun belum memenuhi standar akuntansi. Laporan keuangan yang disusun juga hanya mencatat transaksi secara cash basis. Disisi lain, KEVAmedia menjalankan usahanya dengan mnerima uang muka dari konsumen yang seharusnya diakui sebagai hutang, namun tidak dicatat oleh KEVAmedia. Pemilik bisnis menyadari akan pentingnya pencatatan akuntansi dengan benar dan sesuai cut off serta mencatat laporan lebih akurat dengan metode acrual basis. Namun hal tersebut belum bisa dijalankan karena keterbatasan karyawan. Bahkan satu orang harus mengendalikan beberapa pekerjaan, sehingga tidak bisa dilaksanakan dengan maksimal. Hingga saat ini, penyusunan laporan keuangan disusun untuk memenuhi kebutuhan internal saja. Pemilik bisnis KEVAmedia mengakui akan 
Siti Afidatul Khotijah, Retnosari, Risma Wira Bharata

lebih serius untuk membuat Masa tunggu yang panjang (waktu pembukuan laporan keuangan yang yang dibutuhkan untuk memutuskan lengkap mengenai aktivitasnya dan aplikasi untuk pendanaan) g) sesuai dengan kaidah penyusunan Kurangnya pengetahuan, pemahaman, laporan keuangan yang berlaku, jika kesadaran akan kemungkinan ada pihak ketiga atau investor yang pendanaan awal; h) Karakteristik dan memerlukan. Secara tidak langsung, industri yang tidak menguntungkan; i) ketika bisnis memiliki investor, Status hukum/bentuk perusahaan; j) pengelola akan lebih merasa Kurangnya (berhasil) pinjaman bertanggung jawab untuk melaporkan mikro/pembiayaan dan pendanaan hasil usaha yang telah dijalankan.

Pemilik sekaligus pengelola KEVAmedia masih tergolong muda, dan masih menempuh pendidikan Strata 1. Berdasarkan penelitian Damodaran (2009) dalam (Ryandono, 2018) menjelaskan bahwa terdapat faktor-faktor yang menjadi masalah pada startup dan harus ditangani oleh program yang sesuai untuk menumbuhkan wirausahawan muda. Beberapa permasalahan pendanaan tersebut disebabkan oleh faktor-faktor berikut, yaitu: a) Kurangnya simpanan dan sumber daya pribadi; b) kurangnya sekuritas dan kredibilitas (untuk pembiayaan utang) c) Kurangnya pengalaman bisnis dan keterampilan (untuk pembiayaan utang); d) Metodologi dan peraturan pemberian kredit yang ketat; e) Prosedur dokumentasi yang rumit; f) pembibitan. Faktor tersebut menjadikan perusahaan startup sulit mengakses modal dari perbankan karena tidak bankable. Dengan demikian diperlukan alternatif solusi yang ekonomis dan sesuai dengan kondisi riil perusahaan startup.

Konsep business entity menjelaskan bahwa kekayaan perusahaan haruslah dipisahkan dengan kekayaan pribadi pemilik. Melalui konsep ini setiap transaksi yang berhubungan dengan bisnisnya akan terpisah atau dipisah dnegan transaksi yang berhubungan dengan aktivitas untuk pribadi pemilik (Oesman, 2010). Pemilik yang sekaligus menjadi pengelola utama bisnis ini belum sepenuhnya menerapkan konsep tersebut. Kondisi perusahaan yang memiliki keterbatasan modal, kadang 
mengalami kekurangan modal termasuk baru dan dalam tahap sedangkan pesanan banyak, sehingga tidak jarang pemilik mengeluarkan uang pribadinya untuk digunakan oleh bisnis. Dalam kegiatan transaksi tersebut, pemilik tidak melakukan pencatatan sebagai hutang yang dilakukan usaha kepada pemilik usaha. Hal tersebut menyalahi aturan konsep business entity. Sebaliknya, ketika pemilik membutuhkan uang, kadangkala pemilik menggunakan uang perusahaan yang sedang tidak digunakan/menganggur. Namun pemilik juga tidak melakukan pencatatan bahwa usaha memiliki piutang kepada pemilik. Pemilik sekaligus pengelola menyadari untuk mengembalikan uang usaha yang telah dipakai dan mengambil uangnya yang terpakai untuk keperluan bisnis, hanya tidak dilakukan pencatatan, sehingga hanya pemilik bisnis saja yang tahu adanya transaksi tersebut. Permasalahan berujung lagi kepada keterbatasan karyawan, sehingga pembagian tugas tidak bisa dilakukan dengan baik. Idealnya pemengang kas perusahaan adalah orang yang berbeda dengan pemilik perusahaan, begitu juga untuk bagian pembukuan. Namun karena usaha ini masih perkembangan, sehingga belum bisa menerapkan sistem informasi akuntansi yang seharusnya.

Modal untuk keberhasilan untuk bisnis startup dibutuhkan pengelola startup yang dapat dipercaya, rencana kerja yang terarah, waktu menjalankan yang tepat, gagasan serta finansial yang cukup (Jaya, Ferdiana, \& Fauziati, 2017). Peningkatan inovasi akan berjalan jika didukung adanya knowledge sharing (Suwarno \& Silvianita, 2017). Pemilik yang masih terbilang muda seharusnya bisa lebih menyadari akan pentingnya pembukuan, sehingga pemilik juga harus mencari ilmu bisnis dari pengelola startup yang telah lebih dahulu berhasil. Ilmu yang tidak kalah penting untuk diketahui adalah pembukuan dan konsep akuntansi dan penting diterapkan seperti business entity. Fokus bidang akuntansi dan keuangan biasanya mengambil perspektif eksternal perusahaan (terutama seperti yang diwakili dalam laporan keuangannya) untuk menilai kemungkinan kegagalannya (Davila, Foster, He, \& Shimizu, 2015).

\section{Kesimpulan}


Kesatuan usaha khusus atau business entity merupakan konsep yang memisahkan kekayaan pribadi dengan kekayaan perusahaan yang kita jalankan. Hal tersebut berlaku juga bagi usaha yang masih baru atau sering disebut startup. Penelitian ini menunjukkan bahwa pelaku startup sudah memiliki kesadaran pentingnya menerapkan konsep business entity namun belum bisa diterapkan termasuk pada KEVAmedia karena kendala sumber daya manusia yang masih terbatas, sehingga pembagian tugas belum bisa dilaksanakan. Keberadaan investor juga menjadi salah satu alasan startup untuk menyusun laporan keuangan sesuai kaidah akuntansi dan menerapkan konsep-konsep dalam akuntansi.

Kesadaran menerapkan konsep akuntansi dalam menjalankan bisnis perlu dibangun, sehingga bisa diterapkan. Sejauh ini banyak yang sudah menyadari pentingnya konsep business entity namun belum bisa menerapkan. Saran bagi para pelaku bisinis untuk selalu mengembangkan ilmu termasuk dalam membuat laporan hasil usaha yang sesuai dengan standar yang berlaku. Hal tersebut, akan menarik investor menjadi semakin yakin untuk berinvestasi pada sratup meskipun masih sangat baru. Untuk penelitian selanjutnya, bisa memperluas penelitian di seluruh indonesia untuk mengukur kesadaran pelaku usaha utamanya startup dalam menerapkan business entity. Metode yang digunakan juga bisa menggunakan survei kuisioner untuk bisa menjangkau responden yang lebih luas.

\section{Daftar Pustaka}

Christian Hampel, M. P. (2020). Beyond The Lean Start-Up: Experimentation In Corporate Corporate Entrepreneurship And Innovation. Innovation, 1-11.

Davila, A., Foster, G., He, X., \& Shimizu, C. (2015). The Rise and Fall of Startups: Creation and Destruction of Revenue and Jobs by Young Companies. Australian Journal of Management, 6-35.

Franklin, E. H. (2016). A Rational Approach to Business Entity Choice. Scholarly Works, 572662.

Ginintasasi, R. (2013). Kesadaran Sigmund Freud. Diambil kembali dari File UPI EDU: http://file.upi.edu/Direktori/FI P/JUR._PSIKOLOGI/195009 011981032-

RAHAYU_GININTASASI/K esadaran_Sigmund_Freud_\%5 BCompatibility_Mode\%5D.p df 
Ginintasasi, R. (t.thn.). Kesadaran. Diambil kembali dari File EDU UPI: http://file.upi.edu/Direktori/FI P/JUR._PSIKOLOGI/195009 011981032-

RAHAYU_GININTASASI/K esadaran_Carl_Jung_\%5BCo mpatibility_Mode\%5D.pdf

Gloor, P. A., Dorsaz, P., \& Fuehres,

H. (2011). Analyzing Success of Startup Entrepreneurs by Measuring their Social Network Distance to a Business Networking Hub. Semantic Schoolar.

Isgiyarta, J. (2009). Perumusan Konsep Entitas Akuntansi Islam. JAAI VOLUME $13 \mathrm{NO}$. 1, 77-86.

Jaya, M. A., Ferdiana, R., \& Fauziati, S. (2017). Analisis Faktor Keberhasilan Startup Digital di Yogyakarta. Pros iding SNATI F Ke-4 Tahun 2017, 167-173.

KEVA media. (2019). About KEVA. Diambil kembali dari Kevamedia: kevakit.com/about

Kim, B., Kim, H., \& Jeon, Y. (2018). Critical Success Factors of a Design Startup Business. Sustainability, 1-15.

Mahani, S. A. (2015). Tinjauan Model Inkubator Bisnis Rintisan (Bisnis Startup) di Indonesia. Jurnal Manajemen dan Bisnis: Performa, 76-95.

Matheson, J. H. (2002). Choice of Organizational Form for the Start-Up Business. Minnesota Journal of Business Law and Entrepreneurship, 7-20.

Nugraha, A. E., \& Wahyuhastuti, N. (2017). Startup Digital. Jurnal Nusamba Vol 2 No 1.
Oesman, A. W. (2010). Konsep Entitas dalam Pencatatan Akuntansi Kredit Program pada Koperasi dan Lembaga Keuangan Mikro. JURNAL EKSIS Vol.6 No.1,, 1100 1266 .

Perdani, M. D., Widyawan, \& Santoso, P. I. (2018). FaktorFaktor yang Mempengaruhi Pertumbuhan Sratup di Yogyakarta. Seminar Nasional Teknologi Informasi dan Komunikasi, 337-349.

Rahardjo, B. (t.th). Starting Up. http://budi.rahardjo.id/files/sta rt-up.pdf.

Ryandono, M. N. (2018). FinTech Waqaf: Solusi Permodalan Perusahaan Startup Wirausaha Muda. Jurnal Studi Pemuda, 111-121.

Ryandono, M. N. (2018). FinTech Waqaf: Solusi Permodalan Perusahaan Startup Wirausaha Muda. Jurnal Studi Pemuda, 111-121.

Sheung, C. T. (2014). The New Strategies and e-Business Ethics that Leads Organizations to Success. Journal of Management and Business Research.

Sinaga, M. (1994). Teori Akuntansi. Jakarta: Erlangga.

Suwarno, D. J., \& Silvianita, A. (2017). Knowledge Sharing Dan Inovasi Pada Industri Startup. Jurnal Ecodemica, 98-106.

Wijanarko, Y. (2019, 03 18). Jumlah Starup di Indonesia Ratusan atau Ribuan? Diambil kembali dari Kominfo: kominfo.go.id/content/detail/1 7233/jumlah-startup-diindonesia-ratusan-atauribuan/0/sorotan_media 
Siti Afidatul Khotijah, Retnosari, Risma Wira Bharata

Yanuarti, I., \& Dewi, H. (2018). Zajko, M. (2017). Challenges of Startup Bisnis sebagai Alternatif Investasi: Studi Kasus pada PT. Fiture Teknologi Informasi. ULTIMA Management, 81-96. Scaling-up Process for Startups. International Conference on Engineering and Business Education. 